Recent studies point out at the role of apoptosis disturbances in the development of systemic sclerosis (SSc).

The aim of our study was to examine caspase 1 and sFas serum levels in scleroderma patients and correlate the obtained results with skin involvement and internal organ changes.

We studied 29 patients (14 with limited and 15 with diffuse SSc). The extension of skin involvement was measured using Total Skin Score (TSS). Internal organ involvement was assessed by specialist procedures. Serum caspase 1 and sFas levels were measured by enzyme-linked immunosorbent assay.

We found correlation between sFas serum level and duration of Raynaud's phenomenon and TSS; caspase 1 serum level correlated only with TSS. Correlations between caspase 1 and lung dysfunction and sFas levels with joint and bone involvement in SSc patients were also observed.

The obtained results revealed that disturbances of apoptosis might play a role in SSc pathogenesis. Caspase 1 and sFas serum levels correlate with the skin involvement severity, lung dysfunction, joint and bone changes.

Key words: Systemic sclerosis, sFas, Caspase 1

\section{Evaluation of caspase 1 and sFas serum levels in patients with systemic sclerosis: correlation with lung dysfunction, joint and bone involvement}

\author{
Bozena Dziankowska-Bartkowiak ${ }^{\mathrm{CA}}$, \\ Elzbieta Waszczykowska, Anna Zalewska and \\ Anna Sysa-Jędrzejowska
}

Department of Dermatology, Medical University of Lodz, ul. Krzemieniecka 5, 94-017 Lodz, Poland

\author{
${ }^{\mathrm{CA}}$ Corresponding author \\ Tel. +4842687981 \\ Fax: + 48426884565 \\ E-mail: anuciazalewska@hotmail.com
}

\section{Introduction}

Apoptosis, genetically programmed cell death, plays an important role in embryonogenesis, reparation and regeneration processes. ${ }^{1}$ The disturbance of apoptosis in lymphocytes including autoreactive clones could induce autoantibody production. ${ }^{2,3}$ There are some literature data suggesting that abnormal regulation of apoptosis might be one of the important factors in pathogenesis of systemic lupus erythematosus, rheumatoid arthritis and systemic sclerosis (SSc). ${ }^{4-6}$

Cysteine-aspartic acid-specific proteases (caspases) appear to have important roles in apoptotic execution. ${ }^{7,8}$ Until now, three families of those enzymes, playing different roles in the cells, have been demonstrated: caspases regulating pro-inflammatory cytokine maturation, initiating caspases, and executive caspases.

It is widely accepted that proteolytic enzymes destroy structural and enzymatic cell proteins; however, their precise role has not been elucidated. Caspase 1 is also called interleukin-1 $\beta$ converting enzyme, pro-interleukin-18 and phospholipase $\mathrm{A}_{2}$ converting enzyme. ${ }^{9,10}$ Literature data indicate that the aforementioned proteolytic enzyme, however, is not indispensable in apoptosis, and plays an important role in cytokine release and inflammation devel- opment. ${ }^{9,10}$ All the caspase producing cells, or at least the majority of them, have to have strong mechanisms preventing activation of these enzymes. ${ }^{11}$

Although apoptosis is based on genetically programmed changes in cells, there are some apoptosis regulating factors in the organisms. Some proteins from the tumour necrosis factor family such as myc and Fas (called also APO-1 or CD95) can trigger apoptosis. ${ }^{12}$ Several factors could also inhibit programmed cell death: oncogen bcl-2, excessive amounts of soluble tumour necrosis factor-alpha receptor and antioxidants. ${ }^{7}$

In the group of chronic connective tissue diseases, systemic sclerosis is characterized by dysregulation of the immune system and excessive accumulation of extracellular matrix in the skin and various internal organs. ${ }^{13}$ It seems that imbalance between proapoptotic and anti-apoptotic factors could be responsible not only for immunological disturbances and inflammation, but for internal organ involvement in the course of systemic sclerosis as well, just like in systemic lupus erythematosus. ${ }^{4}$

The aim of our study was to perform measurements of caspase 1 and sFas serum levels in 29 scleroderma patients in comparison with the control group and their correlation with duration of Raynaud's phenomenon, duration of skin involvement and its extent together with internal organ changes. 


\section{Materials and methods}

Our study involved 29 SSc patients, 23 women and six men, age range 16-69 years. In our group, 15 patients presented the diffuse form (dSSc) (mean age, $45.4 \pm 12.1$ years) and 14 patients limited SSc (ISSc) (mean age, $51.6 \pm 12.9$ years). All the patients were diagnosed according to ARA criteria. ${ }^{14}$ Because of the rapid disease progression, all the dSSc patients were on immunosuppressive regimen (50 mg cyclophosphamide daily and $20 \mathrm{mg}$ prednison daily).

Duration of Raynaud's phenomenon and skin sclerosis were evaluated in all the patients. The degree of skin sclerosis was assessed using the Total Skin Score according to Kahaleh et al. (0-66 points). ${ }^{15}$

Four internal organs, the oesophagus, the cardiovascular system, the joint and bone system, and the lung, were evaluated by six specific tests: (1) oesophagal scintigraphy, (2) electrocardiography, (3) Doppler echocardiography, (4) X-ray feet and hand bone, (5) X-ray chest, and (6) lung spirometry. The letter was expressed in percentages of the required value: forced vital capacity (FVC), forced expiratory volume in $1 \mathrm{sec}\left(\mathrm{FEV}_{1}\right)$ and the ratio $\mathrm{FEV}_{1} /$ FVC. Restrictive disturbances of the lungs were diagnosed when FVC was below $80 \%$ of the desired value, while the value of the ratio $\mathrm{FEV}_{1} / \mathrm{FVC}$ was elevated or within the normal range. Obstructing lesions were diagnosed when the value of $\mathrm{FEV}_{1}$ was reduced, and mixed lesions when the reduction in the predicted values of both FVC and $\mathrm{FEV}_{1}$ were similar. ${ }^{16}$ Those parameters were not scored.

Blood was collected in the morning into the pyrogen-free tubes and stored at $-20^{\circ} \mathrm{C}$ until further evaluated. Caspase 1 levels were measured in 17 patients (eight with dSSc and nine with $1 S S c$ ) and sFas in 29 patients ( 15 with dSSc and 14 with $1 S S c$ ). The control group consisted of 10 healthy persons (nine women and one man, aged 25-64 years; mean age, $46.3 \pm 13.2$ years).

Caspase 1 and sFas serum levels were evaluated by enzyme-linked immunoassay (ELISA) technique (Quantikine R\&D Systems Inc., Minneapolis, USA). The detection sensitivity of caspase 1 ranged between 0.22 and $1.24 \mathrm{pg} / \mathrm{ml}$, and the minimum detectable dose of sFas is typically less than $20 \mathrm{pg} / \mathrm{ml}$.
All patients and individuals from the control group gave their informed consent to participate in our study according to the Bioethic Committee of Medical University of Lodz requirements.

\section{Statistical analysis}

The obtained results were expressed as mean, maximum, minimum, and median values together with standard deviation. Numerical variables distribution was assessed by Shapiro-Wilk test. MannWhitney, Cochran-Cox and two independent sample tests were employed for comparison of mean or median values. Correlation between numerical values was evaluated by Spearman range correlation coefficient, $\rho . p<0.05$ was considered statistically significant.

\section{Results}

Characteristics of the patients are presented in Table 1. Table 2 presents abnormalities and changes in internal organs observed in the examined group of patients.

It was demonstrated that mean caspase 1 levels were lower in SSc patients than in the control group $(61.6 \pm 76.4 \mathrm{pg} / \mathrm{ml}$ and $212.4 \pm 246.2 \mathrm{pg} / \mathrm{ml}$, respectively, at $p=0.005)$. It was also observed that dSSc patients demonstrated higher caspase 1 levels than 1SSc ones $(89.7 \pm 87.1 \mathrm{pg} / \mathrm{ml}$ and $36.5 \pm 59.4 \mathrm{pg} / \mathrm{ml}$, respectively, at $p=0.1$ ). Mean serum sFas levels were higher in the patient group than in the healthy controls $(3098.3 \pm 624.4 \mathrm{pg} / \mathrm{ml}$ and $1080.1 \pm 429.5$ $\mathrm{pg} / \mathrm{ml}$, respectively, at $p=0.00005)$. What is more, dSSc patients had higher sFas serum levels than the $1 S S c$ group $(3239.3 \pm 483.2 \mathrm{pg} / \mathrm{ml}$ and $2947.2 \pm 735.3$ $\mathrm{pg} / \mathrm{ml}$, respectively) (Table 3 ).

Statistical analysis with the Spearman range correlation coefficient demonstrated statistically significant, negative correlations between duration of Raynaud's phenomenon and sFas serum levels in systemic sclerosis patients as a whole group $(\rho=$ $-0.549, p=0.002)$ and limited SSc patients $(\rho=$ $-0.672, p=0.009$ ) (Table 4).

We analysed the relationship between serum concentrations of both parameters and extensiveness of skin involvement. We found positive correlations

Table 1. Characteristics of the examined patients

\begin{tabular}{|c|c|c|c|}
\hline & $\begin{array}{l}\text { Systemic sclerosis } \\
\text { patients }\end{array}$ & $\begin{array}{l}\text { Limited systemic sclerosis } \\
\text { patients }\end{array}$ & $\begin{array}{l}\text { Diffuse systemic sclerosis } \\
\text { patients }\end{array}$ \\
\hline Raynaud's phenomenon duration (years) & $11.3 \pm 9.7^{*}$ & $17.0 \pm 11.4^{*}$ & $6.1 \pm 2.8^{*}$ \\
\hline Total Skin Score (points) & $29.9 \pm 13.9$ & $17.7 \pm 4.6^{*}$ & $41.3 \pm 9.0^{*}$ \\
\hline
\end{tabular}

* Differences statistically significant at $p<0.05$. 
Caspase 1 and sFas serum levels in systemic sclerosis patients

Table 2. Abnormalities in the internal organs observed in the examined group of systemic sclerosis patients

\begin{tabular}{llccr}
\hline Type of examination* & $\begin{array}{l}\text { Result of the } \\
\text { examination }\end{array}$ & \multicolumn{3}{c}{ Type of systemic sclerosis } \\
\cline { 3 - 5 } & & $\begin{array}{c}\text { Systemic sclerosis } \\
\text { (total) }(n=29)\end{array}$ & $\begin{array}{c}\text { Limited systemic } \\
\text { sclerosis }(n=14)\end{array}$ & $\begin{array}{c}\text { Diffuse systemic } \\
\text { sclerosis }(n=15)\end{array}$ \\
\hline Oesophagus scyntigraphy & Normal & 7 & 3 & 4 \\
Heart (electrocardiography and & Abnormal & 22 & 11 & 11 \\
Doppler echocardiography) & Abrmal & 16 & 8 & 7 \\
X-ray hand and feet bone & Normal & 13 & 6 & 10 \\
& Abnormal & 21 & 11 & 8 \\
X-ray chest & Normal & 18 & 10 & 7 \\
Spirometry & Abnormal & 11 & 4 & 5 \\
& Normal & 11 & 6 & 10 \\
\hline
\end{tabular}

* Oesophagal scyntigragraphy abnormalities: retarded passage in the lower and/or central part of the oesophagus. Cardio-vascular abnormalities: tendency to tachyarrhythmias, lower potentials of different parameters describing variability of cardiac rythmus or conduction system abnormalities, ventricular arrhythmia, silent ischaemic episodes, diastolic left ventricular disturbances, valvular lesions. Changes in osteo-articular system: juxta-articular demineralization, joint space narrowing in digitals. X-ray chest changes: symmetrical fibrosis of the lung base and 'honey-comb' picture. Spirometry: lung function disturbances of restrictive, obstructive or mixed type.

Table 3. Serum concentration of caspase 1 and sFas in patients with systemic sclerosis and control group

\begin{tabular}{|c|c|c|c|c|c|c|c|c|}
\hline & \multicolumn{4}{|c|}{ Caspase $1(\mathrm{pg} / \mathrm{ml})$} & \multicolumn{4}{|c|}{ sFas $(p g / m l)$} \\
\hline & $\begin{array}{c}\text { Systemic } \\
\text { sclerosis } \\
(n=17)\end{array}$ & $\begin{array}{c}\text { Limited } \\
\text { systemic } \\
\text { sclerosis } \\
(n=9)\end{array}$ & $\begin{array}{c}\text { Diffuse } \\
\text { systemic } \\
\text { sclerosis } \\
(n=8)\end{array}$ & $\begin{array}{l}\text { Control group } \\
\quad(n=10)\end{array}$ & $\begin{array}{c}\text { Systemic } \\
\text { sclerosis } \\
(n=29)\end{array}$ & $\begin{array}{c}\text { Limited } \\
\text { systemic } \\
\text { sclerosis } \\
(n=14)\end{array}$ & $\begin{array}{c}\text { Diffuse } \\
\text { systemic } \\
\text { sclerosis } \\
(n=15)\end{array}$ & $\begin{array}{l}\text { Control group } \\
\quad(n=10)\end{array}$ \\
\hline $\begin{array}{l}\text { Mean } \pm \text { standard } \\
\text { deviation }\end{array}$ & $61.6^{*} \pm 76.4$ & $36.5^{*} \pm 59.4$ & $89.7^{*} \pm 87.1$ & $212.4 \pm 246.2$ & $3098.3^{*} \pm 624.4$ & $2947.2^{*} \pm 735.3$ & $3239.3^{*} \pm 483.2$ & $1080.1 \pm 429.5$ \\
\hline Median & 21.7 & 7.0 & 54.1 & 100.5 & 3064.0 & 2822.1 & 3073.4 & 965.1 \\
\hline Range & $0.0-219.7$ & $0.0-159.4$ & $3.7-219.7$ & $22.6-727.0$ & $1663.3-4435.8$ & $1663.3-4435.8$ & $2513.8-4417.4$ & $594.4-1984.9$ \\
\hline
\end{tabular}

* Statistically significant at $p<0.05$, difference between mean or median value and the control group.

between serum levels of sFas $(\rho=0.365, p=0.05)$ in systemic sclerosis patients as a whole group and Total Skin Score. In contrast, we observed negative correlation between caspase $1(\rho=-0.711, p=0.04)$ and sFas $(\rho=-0.097)$ serum levels and Total Skin Score in the diffuse SSc patient subgroup (Table 4).

We also analysed caspase 1 and sFas serum levels in comparison with organ involvement in systemic sclerosis patients. We observed significantly lower caspase 1 levels in $15 S c$ patients who had more internal organs involved ( $\rho=-0.709, p=0.03$ ).

Statistical analysis showed that the mean value of caspase 1 level was statistically significantly lower in limited SSc patients with pulmonary dysfunction than in those without these disturbances $(p=0.05)$. In the same group of systemic sclerosis patients, mean value of sFas was higher in the patients with joint and bone changes than without them $(p=0.02)$

Table 4. Correlation between caspase 1 and sFas serum levels and duration of Raynaud's phenomenon, duration of skin involvement, Total Skin Score and number of internal organs involved in 29 examined patients with systemic sclerosis

\begin{tabular}{|c|c|c|c|c|c|c|}
\hline \multicolumn{4}{|c|}{ Caspase 1} & \multicolumn{3}{|c|}{ sFas } \\
\hline & $\begin{array}{l}\text { Systemic sclero- } \\
\text { sis }(n=17)\end{array}$ & $\begin{array}{l}\text { Limited systemic } \\
\text { sclerosis }(n=9)\end{array}$ & $\begin{array}{l}\text { Diffuse systemic } \\
\text { sclerosis }(n=8)\end{array}$ & $\begin{array}{l}\text { Systemic sclero- } \\
\text { sis }(n=29)\end{array}$ & $\begin{array}{l}\text { Limited systemic } \\
\text { sclerosis }(n=14)\end{array}$ & $\begin{array}{l}\text { Diffuse systemic } \\
\text { sclerosis }(n=15)\end{array}$ \\
\hline \multicolumn{7}{|c|}{ Duration of Raynaud's phenomenon } \\
\hline$\rho$ & 0.156 & 0.301 & 0.467 & $-0.549 *$ & $-0.672 *$ & 0.141 \\
\hline$p$ & 0.5 & 0.4 & 0.2 & 0.002 & 0.009 & 0.6 \\
\hline \multicolumn{7}{|c|}{ Duration of skin involvement } \\
\hline$\rho$ & 0.082 & 0.026 & 0.147 & -0.288 & -0.370 & 0.261 \\
\hline$p$ & 0.8 & 0.9 & 0.7 & 0.1 & 0.2 & 0.3 \\
\hline \multicolumn{7}{|c|}{ Total Skin Score } \\
\hline$\rho$ & 0.181 & -0.203 & $-0.711^{*}$ & $0.365^{* *}$ & 0.279 & -0.097 \\
\hline$p$ & 0.5 & 0.6 & 0.04 & 0.05 & 0.3 & 0.7 \\
\hline \multicolumn{7}{|c|}{ Number of internal organs involved } \\
\hline$\rho$ & 0.028 & $-0.709 *$ & 0.422 & 0.093 & -0.038 & 0.225 \\
\hline$p$ & 0.9 & 0.03 & 0.3 & 0.6 & 0.9 & 0.4 \\
\hline
\end{tabular}

* Statistically significant.

**P $=0.05$. 


\section{Discussion}

Literature data has reported disturbances in apoptosis in the development of systemic sclerosis. ${ }^{17}$ Szpringer and Lutnicki pointed at considerable inflammatory changes of blood vessels and fibroblast proliferation that could result from either increased production of growth factors or decreased sensitivity of those cells towards apoptosis inducing factors. ${ }^{17}$

Some experimental data suggest that serum catabolic enzymes may influence apoptosis extensivity. It is postulated that inflammatory processes in scleroderma may lead to increased collagen deposition in the tissues. It was demonstrated that caspase 1, caspase 4, caspase 5 and caspase 11 can trigger inflammatory processes. ${ }^{18}$ To the best of our knowledge, there is no literature data on serum caspase level evaluation in systemic sclerosis patients. Our study demonstrated higher mean caspase 1 serum levels in the control group in comparison with systemic sclerosis patients. This observation could suggest that lower serum levels of this protease correlated with apoptosis inhibition in systemic sclerosis patients.

Until now, evaluation of skin lesion severity has been one of the very important parameters of disease activity. We found a strong, statistically significant correlation in diffuse SSc patients between more extensive skin involvement and lower caspase 1 levels. Perhaps this data could account for one of the factors responsible for fibrosis development because more severe apoptosis disturbances are observed in this group in comparison with less severe cases.

Teraki and Shiohara pointed out at the important role of caspase 1 in Fas-triggered apoptotic processes. $^{7}$ Caspase 1 activates effector protease caspase 3 in cysteine protease cascade. Caspase 1 plays an important role in cytokine release and induction of the inflammatory reaction. ${ }^{19}$ It is suggested that lower caspase 1 levels can inhibit apoptosis in the initial stages of systemic sclerosis development, which in turn can activate $\mathrm{T}$ lymphocytes and B lymphocytes. Our data showed correlation between lower caspase 1 serum levels in patients with some internal organs involved. The statistically significant correlation was found only in limited SSc patients with pulmonary dysfunction diagnosed on spirometry. We had assumed that our treatment regimens did not influence caspase 1 levels. Both in patients on either immunosuppressive treatment or vasodilatators and vitamin $\mathrm{E}$, caspase 1 levels were lower than in the control group.

Literature data point out the importance of sFas in apoptosis in the course of autoimmunological disorders. $^{20,21}$ Higher sFas serum levels were demonstrated in patients with rheumatoid arthritis, systemic lupus erythematosus, mixed connective tissue disease, dermatomyositis-polymyositis and silicosis as well as in scleroderma, when comparing with the control groups. ${ }^{3,21}$

The results obtained by us also showed statistically significant higher sFas serum levels in scleroderma patients in comparison with the control group. Those differences seem to depend on the clinical presentation. Serum sFas levels were higher in the dSSc subgroup than in the 1SSc one. We found strong correlations between shorter duration of Raynaud's phenomenon and higher sFas serum concentration. Soluble Fas levels also correlated with skin involvement severity. What is more, patients with joint and bone changes also presented increased sFas serum levels.

It could be assumed that, just like in systemic lupus erythematosus, also in scleroderma higher sFas serum levels may be regarded as a manifestation of some systemic changes. ${ }^{3}$ The observed results are in agreement with the literature data demonstrating importance of sFas in apoptosis triggering in the course of autoimmune diseases. ${ }^{22,23}$

Increased sFas serum levels in systemic sclerosis patients may protect autoreactive $\mathrm{T}$ lymphocytes against apoptosis induced by the Fas ligand system. ${ }^{21}$ Fas stimulation prevents intracellular calcium ions entrance, which is obligatory for lymphocyte $\mathrm{T}$ proliferation, differentiation and cytokine production. ${ }^{4}$ Wetzig et al. demonstrated increased sFas serum levels in the group of 30 scleroderma patients in comparison with the controls. ${ }^{24}$ There were no significant differences in this protein serum level between $1 S S c$ and dSSc patients. This research group concluded that sFas serum levels in scleroderma patients might be only a clinical marker of autoimmune disturbances in the course of this disease but not a reliable parameter of inflammatory process activity.

Our results showed that imbalance between caspase 1 and sFas serum levels could exert an inhibitory effect on apoptosis in patients with systemic sclerosis. Serum levels of caspase 1 and sFas correlated with skin involvement, sFas levels with bone and joint changes, and caspase 1 with pulmonary dysfunction.

ACKNOWLEDGEMENTS. This work was supported by the Medical University of Lodz research grant no. 502-11-697.

\section{References}

1. Wyllie AK, Kerr JFR, Currie AR. Cell death: the significance of apoptosis. Int Rev Cytol 1980; 68: 251-306.

2. Le Roy EC. Increased collagen synthesis by scleroderma fibroblasts in vitro. J Clin Invest 1974; 54: 880-809.

3. Ueki A, Sozaki Y, Tomokuni A, et al. Intramolecular epitope spreading among anti-caspase-8 autoantibodies in patients with silicosis, systemic sclerosis and systemic lupus erythemstosus, as well in healthy individuals. Clin Exp Immunol 2002; 129: 556-561. 
4. Nozawa K, Kayagaki N, Tokano Y, Yagita H, Okumura K, Hasimoto H. Soluble Fas (APO-1, CD95) and soluble Fas Ligand in rheumatic diseases. Arthritis Rheum 1997; 40: 1126-1129.

5. Al-Maini MH, Mountz JD, Al-Mohri HA, et al. Serum levels of soluble Fas correlate with indices of organ damage in systemic lupus erythematosus. Lupus 2000; 9: 132-139.

6. Waszczykowska E, Sysa-Jedrzejowska A, Dziankowska-Bartkowiak B, Narbutt J, Pagounis C, Majewski S. Apoptosis in the skin of patients with autoimmune connective tissue disorders. Centr Eur J Immunol 2001; 26 $53-58$

7. Teraki Y, Shiohara T. Apoptosis and the skin. Eur J Dermatol 1999; 9: $413-426$.

8. Salvesen GS, Dixit VM. Caspases: intracellular signaling by proteolysis. Cell 1997; 91: 443-446.

9. Thornberry NA, Bull HG, Calaycay JR, et al. A novel heterodimeric cysteine protease is required for interleukin-1 beta processing in monocytes. Nature 1992; 356: 768-774

10. Miwa K, Asano M, Horai R, Iwakura Y, Nagata S, Suda T. Casapase 1independent IL- $1 \beta$ release and inflammation induced by the apoptosis inducer Fas ligand. Nat Med 1998; 4: 1287-1292.

11. Wyllie AH. Apoptosis: an overview. Br Med Bull 1997; 53: 451-465.

12. Cohen JJ. Overview:mechanisms of apoptosis. Immunol Today 1993; 14: $126-130$

13. Bunn CC, Black CM. Systemic sclerosis: an autoantibody mosaic. Clin Exp Immunol 1999; 117: 207-208.

14. Subcommittee for scleroderma Criteria of the American Rheumatism Association Diagnostic and Therapeutic Criteria Committee. Preliminary criteria for the classification of systemic sclerosis (scleroderma). Arthritis Rheum 1980; 23: $581-590$

15. Kahaleh MB, Sultany GL, Smith EA, Huffstutter JE, Loadholt CB, LeRoy EC. A modified scleroderma skin score method. Clin Exp Rheumatol 1986; 4: 367-369.
16. Martinez FJ. Badania czynnosciowe ukladu oddechowego. In: Khan MG, Lynch JP III (eds). Choroby pluc. Diagnostyka I terapia. Urban and Partner, 1st edition (in Polish). 2000: 103-120.

17. Szpringer E, Lutnicki K. Znaczenie apoptozy w wybranych chorobach $\mathrm{w}$ dermatologii (in Polish). Nowa Medycyna 2002; 116: 24-32.

18. Zhivotovsky B, Samali A, Gahm A, Orrenius S. Caspase: their intracellular localization and translocation during apoptosis. Cell Death Diff 1999; 8: $644-651$

19. Wang S, Miura M, Yung YK, Zhu H, Li E, Yuan J. Murine caspase-11, an ICE-interacting protease, is essential for the activation of ICE. Cell 1998; 92: $501-509$.

20. Mountz JD, Wu J, Cheng J, Zhou T. Autoimmune disease: a problem of defective apoptosis. Arthritis Rheum 1994; 37: 1415-1420.

21. Bianchi T, Bardazzi F, Patrizi A. Soluble Fas levels in patients with systemic sclerosis. Arch Dermatol Res 2000; 292: 522-523.

22. Tomokuni A, Otsuki T, Isozaki Y, et al. Serum levels of soluble Fas ligand in patients with silicosis. Clin Exp Immunol 1999; 118: 441-444.

23. Sgonc R, Gruschwitz MS, Dietrich H, Recheis H, Gershwin ME, Wick G. Endothelial cell apoptosis is primary pathogenic event underlying skin lesions in avian and human scleroderma. J Clin Invest 1996; 98: $785-$ 792.

24. Wetzig T, Petri JB, Mittag M, Haustein UF. Serum levels of soluble Fas APO-1 receptor are increased in systemic sclerosis. Arch Dermatol Res 1998; 290: $187-190$.

\section{Received 26 August 2003}

Accepted 18 September 2003 


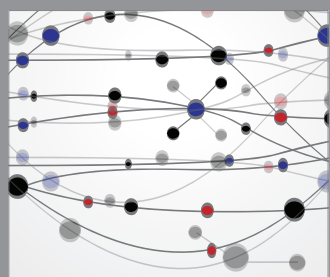

The Scientific World Journal
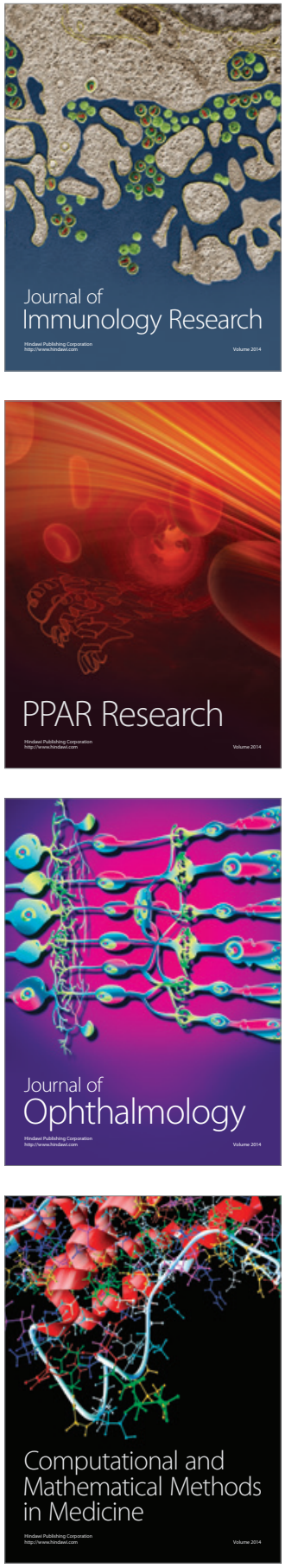

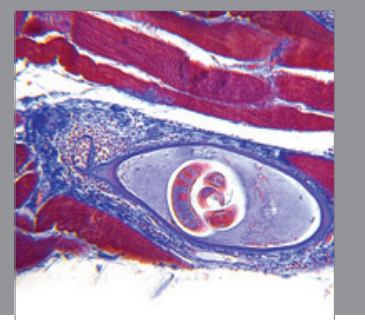

Gastroenterology

Research and Practice
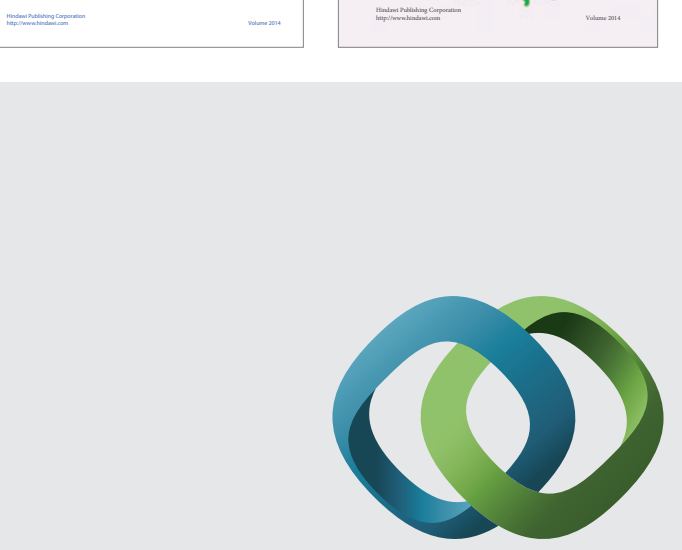

\section{Hindawi}

Submit your manuscripts at

http://www.hindawi.com
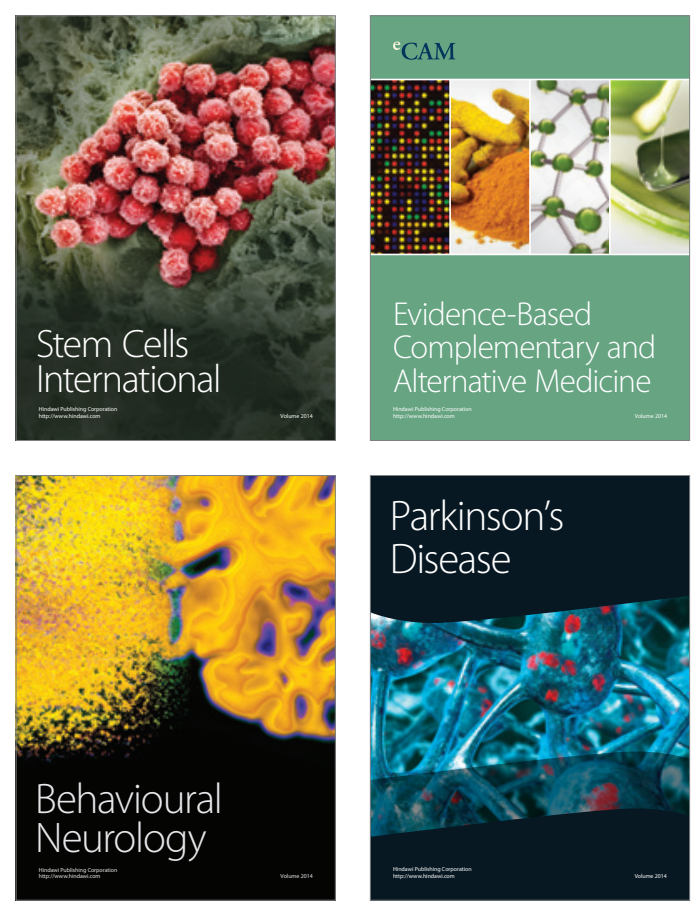

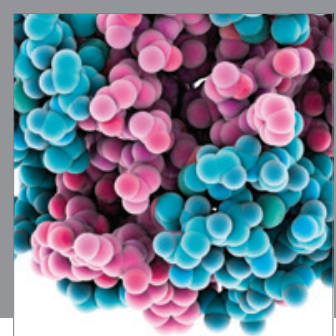

Journal of
Diabetes Research

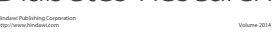

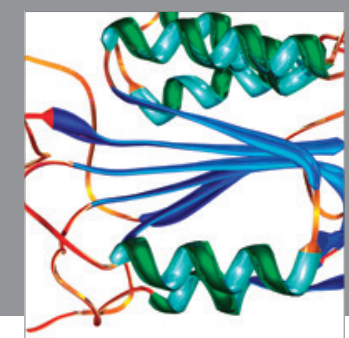

Disease Markers
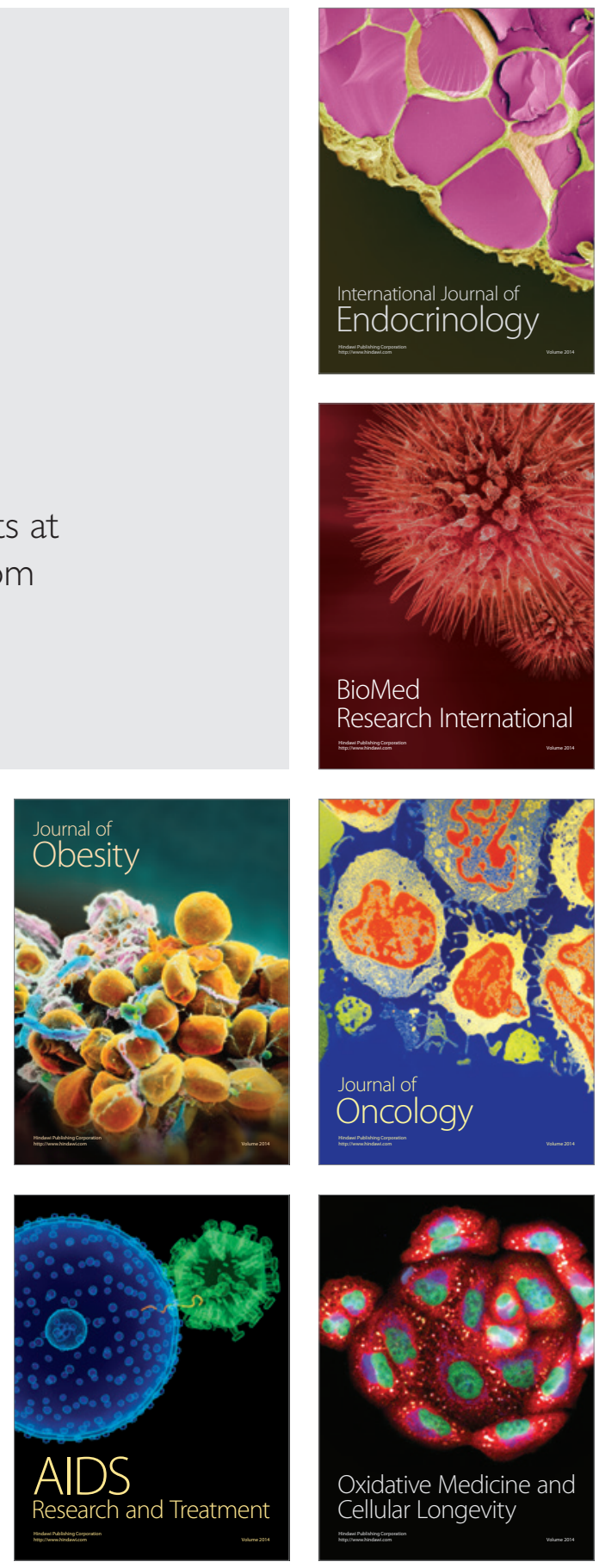